\title{
Genetic Behaviour of Bacterial Wilt Resistance in Brinjal (Solanum melongena L.) in Tropics of Andaman and Nicobar Islands of India
}

\author{
Naresh Kumar Bainsla1,2*, Shrawan Singh1, Pankaj Kumar Singh', Krishna Kumar', \\ Awanindra Kumar Singh1, Raj Kumar Gautam1 \\ ${ }^{1}$ Central Island Agricultural Research Institute, Port Blair, India \\ ${ }^{2}$ Current Address: Division of Genetics, Indian Agricultural Research Institute, New Delhi, India \\ Email: "bainslahau@gmail.com
}

Received 14 December 2015; accepted 20 February 2016; published 23 February 2016

Copyright (C) 2016 by authors and Scientific Research Publishing Inc.

This work is licensed under the Creative Commons Attribution International License (CC BY).

http://creativecommons.org/licenses/by/4.0/

(c) (i) Open Access

\begin{abstract}
Brinjal or eggplant (Solanum melongena L.) is severely affected by bacterial wilt caused by Ralstonia solanecearum in Andaman and Nicobar Islands. Resistant varieties are most suitable option to reduce crop losses from bacterial wilt but knowledge of resistance mechanism and its inheritance is important to develop resistant varieties. Further, majority of germplasm from mainland India showed susceptible reaction under Andaman conditions. Thus, the present study was done during 2010-2012 to understand the genetic behaviour of bacterial wilt resistance in brinjal “CARI-B-1" (R) × "Pusa Purple Long" (S) in hot humid tropical climate of Andaman Islands. For this, the population from single $F_{1}$ fruit was advanced to $F_{2}$ and $F_{3}$ and recorded the reaction of segregating population in the sick plots. The results revealed that there is preponderance of recessive gene family wherein more than one gene acts in additive mode. Another cross between $S$. torvum $(\mathrm{R}) \times$ Diglipur local collection $(\mathrm{S})$ also showed the recessive gene action for resistance as observed in $F_{2}$ generation. Besides, the study also advocated that mechanisms of resistance, escape with early resistance and progressive escape have been found to be operating in individuals of segregating population.
\end{abstract}

\section{Keywords}

Egg Plant, Ralstonia solanecearum, Genetics, Islands, Resistance

\footnotetext{
${ }^{*}$ Corresponding author.
}

How to cite this paper: Bainsla, N.K., Singh, S., Singh, P.K., Kumar, K., Singh, A.K. and Gautam, R.K. (2016) Genetic Behaviour of Bacterial Wilt Resistance in Brinjal (Solanum melongena L.) in Tropics of Andaman and Nicobar Islands of India. American Journal of Plant Sciences, 7, 333-338. http://dx.doi.org/10.4236/ajps.2016.72033 


\section{Introduction}

Brinjal (Solanum melongena L.) is one of the most important vegetable crops of Andaman and Nicobar Islands. These islands are located about $1200 \mathrm{~km}$ from mainland India and have altogether different environmental regime including, soil, precipitation, water and farming practices. Bacterial wilt of Brinjal caused by Ralstonia solanacearum is a serious disease, which limits eggplant production from 4.24 to 86.14 per cent [1] while in islands the disease is devastating in humid and congenial climate and can cause up to $100 \%$ losses. Bacterial wilt is one of the most important diseases of solanaceous crops including brinjal in these islands. Recently, this disease has risen to alarming proportion in the plains of India. Many of the commercial varieties are growing but they are susceptible to this disease [2]. Unfortunately, the majority of resistant varieties developed in mainland India do not survive Island wilt conditions. The resistance reactions and mechanism of resistance are very location and environment specific. Genetic behaviour of bacterial wilt can be depicted from the segregating populations. The dominant and recessive major gene or multiple gene actions help us to decide upon the suitable strategy to develop a resistant variety or hybrid as well as the suitability of donor sources and recurrent parents. A good donor is the line which offers minimum linkage drag, easily maintained and cross compatible and good combining ability. Mechanisms of resistance are also very important to be understood before utilizing the source for any breeding programme. Plants can exhibit immune, resistant, escape, stage specific resistance or a combination of multiple factors in additive or epistatic interaction mode. The resistance reactions and mechanism of resistance are very location and environment specific [3] and the very little success has been attained using chemical control measures [4]. The agency of $\mathrm{R}$ genes present in plants if identified then designing of breeding lines becomes a better choice. Therefore, development of resistant varieties suitable for islands is most economic, eco-friendly and feasible method to ensure better productivity of brinjal. Therefore, the present study was undertaken to understand the genetic behaviour of bacterial wilt of brinjal in tropical islands conditions.

\section{Material and Methods}

For initial idea the brinjal entries from mainland India were screened under sick plot conditions having higher bacterial load $\left(1 \times 10^{7} \mathrm{cfu}\right)$. Seedlings of each entry were raised in sterile soil media without any biotic stress. The one month old seedlings were transplanted in sick plot for evaluation of disease reaction. The "CARI-B-1" is resistant to bacterial wilt and bear green oblong fruits [5] while "PPL" is a susceptible parent for bacterial wilt and produce purple fruits in clusters (AICRP-VC, 2012).

The segregating population were developed by selfing of single $F_{1}$ plant and resistant plants of $F_{2}$ were used for development of $F_{2-3}$ families. A set of 42 plants from each $F_{2}$ surviving plants were used for observations in sick plot having sufficient inoculum load of $\left(1 \times 10^{7} \mathrm{cfu}\right)$ of the pathogen. The segregating population was raised in close spacing $(60 \times 40 \mathrm{~cm})$ with raised with proper package of practices as described by [6]. The observations were recorded on bacterial wilt incidence on fortnight basis. The percent disease incidence was recorded by PDI $=\frac{\text { Number of wilting plants in a family }(w)}{\text { Total number of plants in each family }(n)} \times 100$. The progeny families were then plotted against percent disease incidence on given fortnight intervals order to understand the progressive disease development pattern in the form of regression equation and $\mathrm{R}^{2}$ values were taken as best estimate of regression model. The genetic ratios were tested based upon goodness of fit for inheritance using chi-square test.

\section{Results}

\subsection{Disease Reaction in Mainland Entries}

30 lines of cultivated brinjal (Solanum melongena) obtained from mainland All India Coordinated Research Project (AICRP) on vegetable crops were tested against wilt incidence under sick plot conditions in research farm of Central Island Agricultural Research Institute, Port Blair, which is situated in South Andaman. The bacterial wilt (BW) incidence ranged from $11.67 \%$ - 96.67\% with mean value of $60 \%$. None of the line showed full resistance to bacterial wilt, however line BRBWRES1 showed better performance as compared to check and other lines with only $11.67 \%$ disease incidence during first two months however, later on this also collapsed with exponential expression of bacterial wilt. 


\subsection{Disease Reaction in Biparental Segregating Population}

A biparental segregating population from (“CARI Brinjal 1" × "Pusa Purple Long”) cross was developed. From single F1 fruit the $\left(\mathrm{F}_{2}\right)$ population comprising of 67 plants was developed. Out of 67 plants only 22 plants survived up to 60 days. This suggested a simple fitting ratio of 1:3 showing recessive major gene action (Table 1). Out of these 22 plants five plants did not bear any flower and fruit and one typical character of these five plants was that these were highly pigmented. Only 17 could be taken to next level $\left(\mathrm{F}_{3}\right)$ due to problem in fruiting of five plants. However, further dissection of the resistance in $\mathrm{F}_{3}$ progeny families indicated towards the complex nature of bacterial wilt genetic behaviour. A total of $17 \mathrm{~F}_{3}$ progeny families each comprising 42 plants in fruit to row manner were evaluated in bacterial wilt sick plot along with two replicated checks viz. Check 1 (Diglipur local ) and Check 2 (CARI Brinjal 1) The disease reaction was recorded at fortnightly intervals. Family of plants derived from ANBF3-11-57 progeny showed no mortality up to fifth fortnight and mortality reached $33 \%$ in this group at the end of sixth fortnight. A polynomial regression equation of order 4 was best fitted to this family with coefficient of determination $\mathrm{R}^{2}$ value of 0.996. ANBF3-11-16 and ANBF3-11-62 progenies behaved like Check 2 exhibited an initial mortality of less than 20\% up to fourth fortnight and then slight increase in fifth and sixth fortnight reaching to $31 \%$. These two progeny families depict a typical resistant category following an exponential regression trend line with $\mathrm{R}^{2}$ value of 0.946 .

Three progeny families viz. ANBF3-11-04, ANBF3-11-11 and ANBF3-11-20, followed Check 1 (Diglipur local) with an exponential regression trend line with $\mathrm{R}^{2}$ value of 0.944 which showed breakdown of resistance during $5^{\text {th }}$ and $6^{\text {th }}$ fortnights suggesting that such plants can show moderate level of resistance for economic harvest of the crop. It also indicates that factor for inducing resistance at later stage are lacking in these lines and escape mechanism is operating. ANBF3-11-29, ANBF3-11-50 and ANBF3-11-64 exhibited a linear trend with $\mathrm{R}^{2}$ value of 0.986 and moderate susceptibility. The regression trend line of five progeny families' viz. ANBF311-03, ANBF3-11-09, ANBF3-11-27, ANBF3-11-30, and ANBF3-11-41 were also found to exhibit linear progression of disease development with a greater slope indicating higher susceptibility. The progeny families ANBF3-11-47, ANBF3-11-49 and ANBF3-11-67 showed a sudden breakdown of resistance in second and subsequent fortnights and these families fall in highly susceptible category following a high order polynomial regression equation with $\mathrm{R}^{2}$ values of 0.989 to 0.996 . This analysis indicate that though the resistance against bacterial wilt is governed by recessive gene action yet there preponderance of complex genic interactions due as revealed by the regression analysis. Another interpretation of results indicate that if we classify all the families in two categories of resistant and susceptible keeping resistant bar up to $40 \%$ mortality and consider duration of observations up to 75 days after transplanting than it fits well in goodness with 1:3 category though it seems to be convenient for backing up the previous findings, however it is ambiguous and contradictory to the fact that there is existence of two classes in resistant category and three classes in susceptible category wherein at fifty percent plants are surviving up to fifth fortnight in one category giving some yield and there is $50 \%$ mortality in fourth fortnight which is peak period of reproductive stage of plant and the third category which is dying in vegetative stage itself (Table 2). The mechanism of resistance is shown by the progeny families which show a parallel line with time Figure 1(a) and Figure 1(b). Few entries also express early resistance and then breakdown which help in escape Figure 1(c) while the third category shows progressive escape with slow mortality Figure 1(d). The Fourth category is of progressive susceptibility with time as the inoculum multiplies in the rhizosphere Figure 1(e) while the fifth category shows a sudden breakdown at early stage itself suggesting highly susceptible reaction Figure 1(f).

Table 1. Chi-square values of different segregating populations.

\begin{tabular}{|c|c|c|c|c|c|c|}
\hline Sl. No. & Population & $\begin{array}{l}\text { Resistant plants/ } \\
\text { progeny families }\end{array}$ & $\begin{array}{l}\text { Susceptible plants/ } \\
\text { progeny families }\end{array}$ & $\begin{array}{l}\text { Chi square value } \\
\text { for resistant plants }\end{array}$ & $\begin{array}{l}\text { Chi square value for } \\
\text { susceptible plants }\end{array}$ & $\begin{array}{c}\text { Cumulative } \\
\text { chi-square value }\end{array}$ \\
\hline 1 & $\begin{array}{l}\mathrm{F}_{2} \text { CARI Brinjal } 1 \times \\
\text { Pusa Purple Long }\end{array}$ & 17 & 50 & 0.00373 & 0.00124 & 0.00497 \\
\hline 2 & $\begin{array}{c}\mathrm{F}_{3} \text { CARI Brinjal } 1 \times \\
\text { Pusa Purple Long }\end{array}$ & 4 & 13 & 0.0147 & 0.00490 & 0.0196 \\
\hline 3 & $\begin{array}{l}F_{2} \text { S. torvum } \times \\
\text { Diglipur local }\end{array}$ & 9 & 31 & 0.1 & 0.1 & 0.2 \\
\hline
\end{tabular}




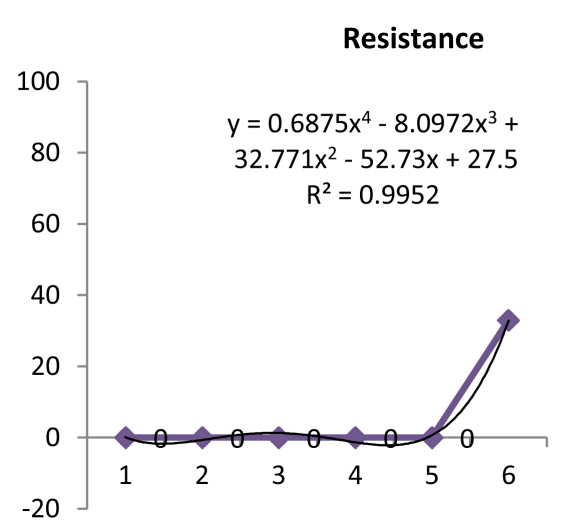

(a)

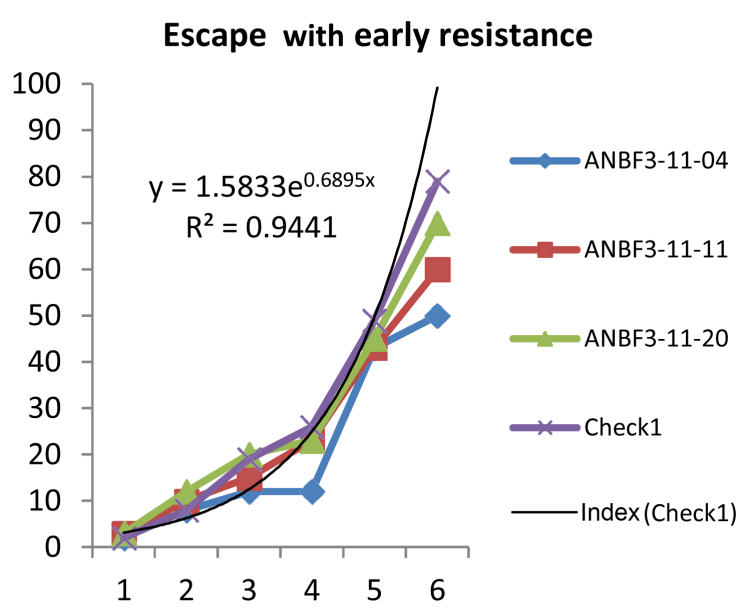

(c)

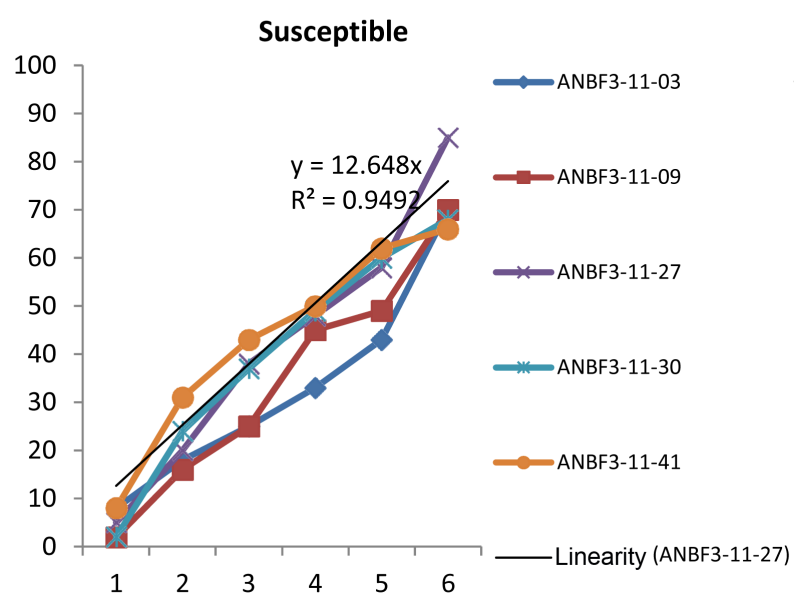

(e)

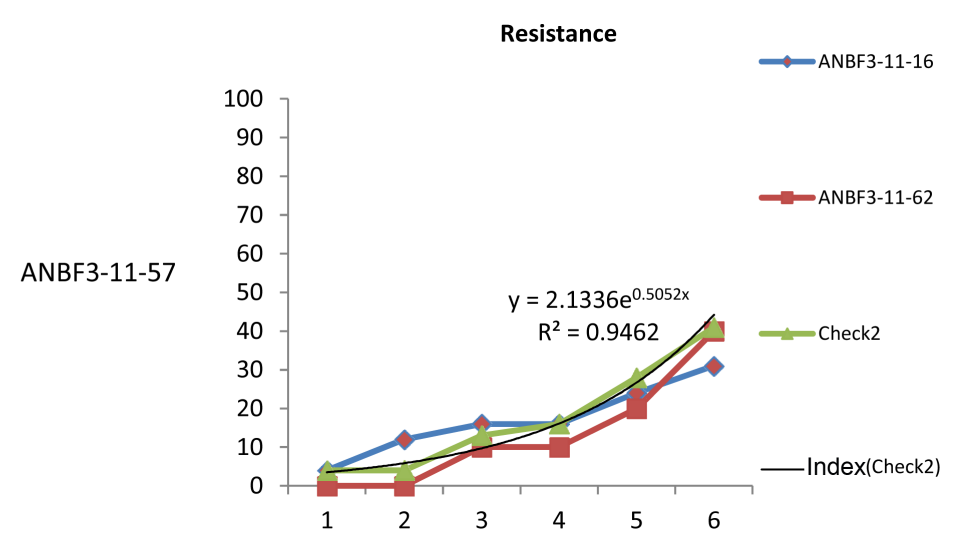

(b)

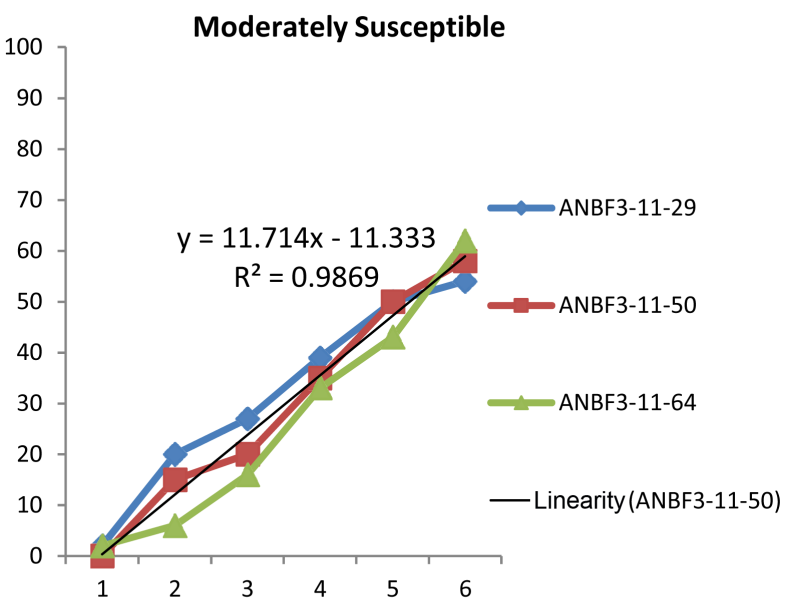

(d)

Highly Susceptible

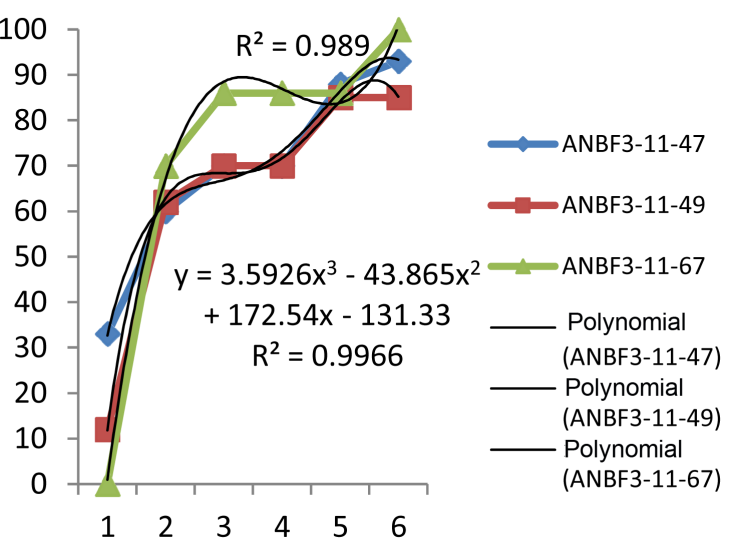

(f)

Figure 1. Resistance mechanisms prevalent in segregating population. (a) and (b) resistance mechanism (Resistance reaction exhibited by three families and CARI Brinjal-1 as check2); (c) moderately resistant with Early Resistance + escape mechanism; (d) progressive linear susceptibility; (e) susceptible; (f) highly susceptible. Note: X-axis is the fortnightly (15 days) interval and Y-axis depicts the percent disease incidence.

This indicates there is more than one gene involved in governing stage specific resistance or there is agency of modifiers/transcription factors which result in differential expression of resistance action over the time. In total five categories of resistance reactions were observed in $\mathrm{F}_{3}$ progenies. It seems to be an additive effect of dif- 
Table 2. Percent disease incidence in progeny families.

\begin{tabular}{|c|c|c|c|c|c|c|c|}
\hline \multirow{2}{*}{ S. No. } & \multirow{2}{*}{ Progeny family } & \multicolumn{6}{|c|}{ \% Disease incidence after transplanting } \\
\hline & & 15 days & 30 days & 45 days & 60 days & 75 days & 90 days \\
\hline 1 & ANBF3-11-16 & 4 & 12 & 16 & 16 & 24 & 31 \\
\hline 2 & ANBF3-11-57 & 0 & 0 & 0 & 0 & 0 & 33 \\
\hline 3 & ANBF3-11-62 & 0 & 0 & 10 & 10 & 20 & 40 \\
\hline 4 & Check2 & 4 & 4 & 13 & 16 & 28 & 41 \\
\hline 5 & ANBF3-11-04 & 2 & 8 & 12 & 12 & 43 & 50 \\
\hline 6 & ANBF3-11-29 & 2 & 20 & 27 & 39 & 50 & 54 \\
\hline 7 & ANBF3-11-50 & 0 & 15 & 20 & 35 & 50 & 58 \\
\hline 8 & ANBF3-11-11 & 3 & 10 & 15 & 23 & 43 & 60 \\
\hline 9 & ANBF3-11-64 & 2 & 6 & 16 & 33 & 43 & 62 \\
\hline 10 & ANBF3-11-03 & 8 & 18 & 25 & 33 & 43 & 70 \\
\hline 11 & ANBF3-11-20 & 3 & 12 & 20 & 23 & 45 & 70 \\
\hline 12 & Check1 & 2 & 8 & 19 & 26 & 49 & 79 \\
\hline 13 & ANBF3-11-09 & 2 & 16 & 25 & 45 & 49 & 70 \\
\hline 14 & ANBF3-11-30 & 2 & 24 & 37 & 49 & 60 & 68 \\
\hline 15 & ANBF3-11-27 & 5 & 20 & 38 & 48 & 58 & 85 \\
\hline 16 & ANBF3-11-41 & 8 & 31 & 43 & 50 & 62 & 66 \\
\hline 17 & ANBF3-11-49 & 12 & 62 & 70 & 70 & 85 & 85 \\
\hline 18 & ANBF3-11-47 & 33 & 60 & 70 & 70 & 88 & 93 \\
\hline 19 & ANBF3-11-67 & 0 & 70 & 86 & 86 & 86 & 100 \\
\hline
\end{tabular}

ferent genes comprising a gene family which impart resistance at different levels of plant development and absence of allele causes stage specific susceptibility.

Similar effects have been observed in another segregating population $\left(\mathrm{F}_{2}\right)$ of a local susceptible accession of cultivated brinjal (S. melongena) and wild relative S. torvum which is highly resistant to all kinds of wilts. The $F_{2}$ progeny raised from the single fruit of $F_{1}$ plant comprising of 110 plants. A set of 40 plants was inoculated with the Ralstonia solanecearum $\left(1 \times 10^{8} \mathrm{cfu}\right)$ after 21 days of transplanting. 31 plants died within 30 days after inoculation while 9 plants survived suggesting a recessive inheritance of bacterial wilt. However, the mortality of plants was not sudden rather it happened over a period of time. When we plot the results on line diagram and observe we can see the different categories of resistance reaction indicating the mechanisms of resistance prevalent in the segregating population.

\section{Discussion}

The study of inheritance pattern of resistance to many biotic stresses is helping the plant breeders to device suitable methods to develop resistant hybrid/variety. The bacterial wilt inheritance is race, biovar, strain, genotype and environment specific and it is genetically determined. There are different schools of thought over the number of genes and dominance behaviour of resistance. Many workers have reported the resistance to be governed by single dominant gene [2] [7]-[9] and they have also mentioned that single gene inheritance for bacterial wilt resistance. Swaminathan and Srinivasan [8] studied the resistance to P. solanacearum in the hybridization between eggplant cultivar purple long Dutta and Solanum melongena var. insanum and reported the latter carried a single dominant gene for resistance and purple long Dutta carried a recessive gene. Vijayagopal and 
Sethumadhavan [10] confirmed the above study by attempting intervarietal hybrids of the same cross i.e., Solanum melongena Pusa Dutta $\times$ Solanum melongena var. insanum and reported resistance to Pseudomonas solanacearum was dominant and monogenic controlled. Resistance to bacterial wilt was inherited as single dominant gene character in the cross WCGR-112-8 and Pusa kranti in brinjal [2] which was also the case of the resistance to bacterial wilt in "Nihan nassu" cultivar was due to the presence of single dominant gene [11]. Study on the 11 hybrid families from Solanum phureja $\times$ Solanum tuberosum crosses indicated that, resistance was controlled by three dominant independent genes [12]. Chaudhary [13] reported that the bacterial wilt was controlled by polygenes. The inheritance pattern for bacterial wilt resistance has been reported ranging from monogenic dominant/ recessive to inhibitory type in different cross combinations by different workers. Feng et al. [14] concluded that the inheritance of bacterial wilt resistance as additive-dominant model. Additive, dominant and recessive effects played major role in the genetics of bacterial wilt resistance, with additive effects being the dominant factor. Bacterial wilt resistance was controlled by number of minor, major and cytoplasmic genes. However, the current study supports inheritance study of susceptibility to bacterial wilt was dominant over resistance in brinjal [15].

\section{Acknowledgements}

The authors acknowledge the active support of field and laboratory staff. Authors also acknowledge the support of Director, CIARI for providing suitable funding and resources for conducting this study.

\section{References}

[1] Sabita, J.N., Boruah, B.M. and Rachid, H.A. (2000) Yield Potentiality of Some Brinjal Cultivars in Severely Bacterial Wilt Infected Condition. Vegetable Science, 27, 76-77.

[2] Gopinath, G. and Madalageri, B.B. (1986) Bacterial Wilt (Pseudomonas solanacearum E. F. Smith) Resistance in Eggplant. Vegetable Science, 13, 189-195.

[3] Mew, T.W. and Ho, W.C. (1977) Effect of Soil Temperature on Resistance of Tomato Cultivars to Bacterial Wilt. Phytopathology, 67, 909-911. http://dx.doi.org/10.1094/Phyto-67-909

[4] Ali, M., Quadir, M.A., Okubo, H. and Fujieda, K. (1990) Resistance of Eggplant, Its Wild Relatives and Their Hybrids to Different Strains of Pseudomonas solanacearum. Scientia Horticulturae, 45, 1-9. http://dx.doi.org/10.1016/0304-4238(90)90062-J

[5] Krishna, K., Singh, P.K., Ajanta, B., Shrawan, S., Naresh, K., Singh, A.K., Singh, D.R. and Gautam, R.K. (2012) CARI Eggplant-1 (IC0585684; INGR12015), an Eggplant Germplasm with Bacterial Wilt Resistance. Indian Journal of Plant Genetic Resources, 25, 323-324.

[6] Bose, T.K., Kabir, J., Maity, T.K., Parthasarathy, V.A. and Som, M.G. (2002) Vegetable Crops. Vol. 1, Naya Prokash Kolkata.

[7] Ajjappalavara, P.S., Dharmatti, P.R., Salimath, P.M, Patil, R.V., Patil, M.S. and Krishnaraj, P.U. (2008) Genetics of Bacterial Wilt Resistance in Brinjal. Karnataka Journal of Agricultural Sciences, 21, 424-427.

[8] Swaminathan, M. and Srinivasan, K. (1972) Studies on Brinjal Hybridization. Transference of Bacterial Wilt Resistance from Wild Brinjal Variety. Agricultural Research Journal of Kerala, 9, 11-13.

[9] Zhu, H., Yao, Y.G., Liu, Z.M., Yang, J.G. and Chen, H.M. (2004) On Resistance to Bacterial Wilt in Eggplant (Solanum melongena L.). J. Hunan Agric. Univ. (Natural Science Edition), 30, 288-289.

[10] Vijayagopal, P.D. and Sethumadhavan, P. (1973) Studies on the Intervarietal Hybrids of Solanum melongena L. Agricultural Research Journal, Kerala, 11, 43-46.

[11] Akiba, F. (1972) Resistance to Bacterial Wilt in the Eggplant Variety “Nihon Nassu” A \& G. University Fed. Rus., Rio de Janeiro, 2, 17-21.

[12] Rowe, P.E. and Sequeria, L. (1970) Inheritance of Resistance to Pseudomonas solanacearum in Solanum phureja. Phytopathology, 60, 1499-1501. http://dx.doi.org/10.1094/Phyto-60-1499

[13] Chaudhary, D.R. (2000) Inheritance of Resistance to Bacterial Wilt (Ralstonia solanacearum E. F. Smith) in Eggplant. Haryana Journal of Horticultural Sciences, 29, 89-90.

[14] Feng, L.L., Qu, D.Y., Jin, L. and Liang, Y. (2003) Genetic Analysis of Resistance to Bacterial Wilt (Ralstonia solanacearum) in Eggplant (Solanum melongena L.). Acta Horticulture-Sinica, 30, 163-166.

[15] Gopalakrishnan, T.R., Singh, P.K., Sheela, K.B., Shankar, M.A., Kutty, P.C.J. and Peter, K.V. (2005) Development of Bacterial Wilt Resistant Varieties and Basis of Resistance in Eggplant (Solanum melongena L.). In: Allen, C., Prior, P. and Hayword, A., Eds., Bacterial Wilt Disease and the Ralstonia solanacearum Species Complex, 293-300. 